\title{
Determinants of Population Growth Trends for Tanzanian Small Towns
}

\author{
Ally Hassan Namangaya \\ School of Spatial Planning and Social Sciences, Ardhi University, Dares Salaam, Tanzania \\ Email address: \\ namangaya@yahoo.com

\section{To cite this article:} \\ Ally Hassan Namangaya. Determinants of Population Growth Trends for Tanzanian Small Towns. Urban and Regional Planning. \\ Vol. 4, No. 2, 2019, pp. 67-78. doi: 10.11648/j.urp.20190402.13
}

Received: April 26, 2019; Accepted: July 9, 2019; Published: July 19, 2019

\begin{abstract}
The largest share of urbanisation in Sub Saharan Africa is taking place in settlements that are smaller than cities. However, these small urban settlements are conceptually neglected and mostly mistheorised as overriding land governance concepts and institutional procedures were designed for large urban centres or the extreme opposite, villages. As a result, there is either a total lack of specific policies on small urban centres or the policies are designed wrongly thus contributing to challenges of informality, poor servicing and environment degradations. This paper, using the Tanzanian case, is an attempt to contribute in understanding the dynamics of small towns through establishing the population thresholds that can appropriately be classified as small towns and the factors driving their growth. The study analyses census data spatially using geographical information system and statistical software. The results indicate that the typical size of small towns where polarisation forces still gravitate towards the town has a number of people between 10,000 and 50,000 people with population density at the core of the settlements ranging from 40 to 120 people per hectare. The major factors for the development are the presence of economic activities that have value addition options contributing to off-farm employment, and the typical radius of its hinterland for each small town is about a one hour drive. As the number of small towns continues to grow in Sub Saharan Africa due to continued polarisation forces, policies and interventions for the management of small have to be pre-emptive and anticipatory.
\end{abstract}

Keywords: Small Towns, Tanzania, Urban Planning, Urban Population Growth

\section{Gaps in the Understanding of Small Towns}

As the world is urbanising, it has reached a stage where 63 per cent of the urban population is concentrated in intermediate and small towns [1-4]. Contrary to the European and North American experiences, where most of the small towns are experiencing decline or stagnation of population growth $[5,6]$ in sub-Saharan Africa, there is an increase in population of small towns. This trend calls for a rethinking of policy focus on issues that impact on small towns in subSaharan Africa. Despite this realisation, there is a tendency to see development in extremes of cities and rural areas that leave a void in academic discourse and policies specific for small towns $[7,8]$.

The tendency to marginalise small towns at the expense of villages and large urban centres has a long history in sub-
Saharan Africa. During independence days (the 1960s) governments, which mostly subscribed to modernisation theories were subsidizing the cost of living in major urban centres, thus had to some extent neglected small towns [9]. Early indications of failures of moderation theories corresponded with the strengthening of socialistic ideas in some countries, including Tanzania, saw the rekindling of interests in small towns as a tool to drive rural development. Donors through their technical agencies financed projects such as Integrated Rural Developments Plans [9, 10], in which small towns were conceptualised as development nodes to service the hinterlands. The structural adjustment and decentralisation programmes from the very early 1980 s to late 1980s shoved requirement to have minimalist states in sub-Saharan African countries, reducing the role of governments thus un-intentionally favouring large urban centres [11]. Since then small towns and large urban centres in sub-Saharan Africa have been proliferating in the 
liberalised economies without clear guidance. This resulted in multiple maladies such as informal urbanization and poor servicing in all urban areas. In Europe, too small towns were neglected for some years because at the time the metropolises were desired centres of consumerism and small towns were left to meet natural death $[6,12]$.

Since the early 1990s, there have been global efforts to improve the state of urban planning in Tanzania and other African countries, mostly under UNEP and UN-HABITAT support, however, these attempts were undertaken mostly in complex megacity contexts, with donor-funded programmes $[12,13]$. Small towns are under rural councils with comparatively lower human and financial capacities [14]. Absence or under the capacity of small towns' planning institutions failed to capture many potentials existing in small towns that would make planning concept adaptable and implementable. These potentials include low population sizes, the relative abundance of affordable land and cohesive communities $[5,15,16]$.

As thrust towards urban and regional competitiveness dominates the spatial planning discourses, interests on small towns as a part of overall regional competitiveness and prosperity has been rekindled $[17,18]$. Different from the Global North where the issue is mostly rejuvenation of vibrancy and deteriorating infrastructure in small towns, in the Global South, the issue is, there has been very low infrastructure investments and policy neglect in small towns despite burgeoning population [8]. Sharma [19] summarises problems of small towns to be financing gap and lack of spatial development planning. In Tanzania, the Tanzania National Audit Office 2014 [20] shows that the challenges is not only that 80 per cent of the towns do not have spatial plans, but even those with the plans never implement them (as reflected in physical development patterns). The same situation is widely reported in Tanzania and other Sub Saharan countries [21-24].

To be able to formulate effective policies to guide the development of small towns requires the understanding of such towns, the fact which unfortunately has been ignored by the scientific community where the assumption has probably been by understanding large urban centres, policy makers and planners will automatically gain insights on development dynamics of small towns [25]. As a result of this neglect, there are many unanswered questions which hamper formulations of effective policies. Some of the questions this research paper intends to answer are; what is the range of population size that would represent a small town? and what are main factors for the emergence and populations growth of small towns? The discussions here under highlights some of the discourses on these issues.

\section{Population Sizes in Small Towns}

There is a wide range of population size used to define the small towns. These population ranges are context-dependents. There are countries where small towns are considered to be in the lowest hierarchy of population concentration. In these countries, the population sizes of small towns are considered to be below 20,000. These include the United States of America and Western Europe counties [26-29]. The other set is those countries where there are village settlements below the small towns in the settlements hierarchy. In the second type of contexts, the population range of small towns has the upper limit of 100,000 people [15]. In these contexts, there are many variations on the minimum and average population size of small towns. For instance, Japan only considers small towns when population size is above 30,000 [26] while many others have set an average of 50,000 [30,31]. In Tanzanian there are conflicting designations and criteria used to define small towns between three central government institutions, namely then ministry responsible for lands, the ministry responsible for local government and the National Bureau of Statistics [32, 33].

A few authors have included density criteria to standardise more on the definitions of small towns. Rebernik [34] in the case of Slovenia, states the gross density range to be between 250 and 500 people per $\mathrm{km}^{2}$. Equally, Sharma [19] discussing the case of India states the minimum gross density for a small town to be 400 people per $\mathrm{km}^{2}$. These are extreme low densities designated for small towns, considering a benchmark Gordon and Richardson [35] have set when discussing the distributions of worldwide urban densities that the minimum urban population density for sustainable development should be between $16,000-20,000$ people per $\mathrm{km}^{2}$ or $40-50$ dwelling units per hectare. A study conducted in Tanzanian cities found out that the average gross density on urban areas is around 21 dwelling units per hectare or 8400 people per $\mathrm{km}^{2}$ [24].

\section{The Theoretical Explanation for Urban Populations Growth}

In theory, the urban population growth cycle is a function of regional population interactions among urban centres [26, 36] [37]. In this cycle, small towns' urbanisation path starts when they absorb more populations from hinterland through migrations and natural growth such that their growth rates exceed those of surrounding settlements. As they grow they also feed part of their populations into regional cities and therefore as long as the regional cities are growing they will continue to emerge and grow. However, their growth rates will be decreasing (measured between intercensal periods) until they stabilise, this is when the regional centres go into polarisations reversal or stagnations. Possibly a new growth cycle starts again. As African urbanisation has generally not reached the point of stabilisation and reversal, this it is only possible to establish declining trends of growth of small towns from the falling rate of immigration and structural change in small towns that had a very specific economic base like mining [37].

\section{Determining Context-Relevant Factors for Populations Growth in Small Towns}

Local Economic Development (LED) framework, which is 
based on endogenous development and economic base theories, is one of many possible theoretical frameworks that could be used to explain the rationale for the number of people and capital to concentrate and grow in a particular settlement $[38,39]$. Under the LED theorisation, the basic reason for the people to move to particular locations are mainly employment opportunities and liveability. An important condition for the employment opportunities to be generated in excess of the internal settlement's labour supply is to have the endowment of resources within the settlement or its vicinity as well as to attract and nature capital so that there are expansions of productions activities.

Natural endowments that make production activities possible in a context of developing countries like Tanzania where 77.5 per cent of labour force relies upon agriculture [40] include access to usable agricultural land and water, availability of forest and wildlife resources and presence of mineral resources. Usable indicators for potentiality for agriculture to thrive include presence of rivers, distance to the city and distance to the competing urban centres and regional centres which provides the market for its produces and define catchment for its productions activities. Presence of conservations areas is a proxy in the richness of biodiversity (wildlife and/or forest resources). On the other hand, the presence of protected biodiversity areas may restrict lateral growth of other types of activities including housing development. Tourism sector, albeit potentially relevant for attracting migrant labour and capital, is limited by the poor state of infrastructure in small towns and the structure of the national economy, in which main tourism offices are in large urban centres [41].

For the settlement to attract capital and become more competitive than its peers, it has to express interconnectedness and agglomeration economies [42]. Interconnectedness means linkage to other markets which reduces costs of productions and expands the customer base. To be interconnected in the context of developing countries is to have a transport node such as highway linkages to other areas and train stations. Agglomeration economies in the context of developing countries means having basic sector economic activities, mainly in agriculture and mining that attracts other industries businesses and capital for its expansion [40, 43]. Therefore relevant indicators for the proximity and growth of productions activities include the existence of large estate farms, the presence of separate crop processing factories and the proximity to large government agricultural projects. Expansion of agricultural areas also can indicate the growth in production activities. Political resources such as declarations of a settlement as a district administrative centre, has the same effect as the introduction of economic activities through government offices that provide employment and generate customers for some producers of goods and services. Cost of doing business, in addition to the level of interconnectedness, is also reduced by the quality of labour especially as they serviced higher order facilities like large hospitals and universities.

\section{Data and Methods}

The study approach involved using Geographic Information Systems (GIS), and the specific software used are ArcGIS and QGIS, to analyse changes in spatial coverages, density levels and proximity of functions, facilities and resources to the town centres (similar studies include Deng [44] and Masron [45]. Statistical Package for Social Studies (SPSS) was used for correlation analysis and establishment of central tendencies, while Past 3.24 was used for Principle Component Analysis. All the factors were assessed as they relate to the settlements' population growth. The list of factors tested, methods and intention of the test are summarised in Table 1. The actual data generated and used for analysis are presented in Appendix 1.

Table 1. Data used and essence of their analysis.

\begin{tabular}{|c|c|c|}
\hline Factor & Methods of analysis & The rationale for the analysis \\
\hline $\begin{array}{l}\text { Wards populations, } 1978,1988 \text {, } \\
2002,2012\end{array}$ & $\begin{array}{l}\text { Ward population and boundary data for } 1988,2002,2012 \\
\text { had to be combined if a particular ward was subdivided to } \\
\text { reflect the boundaries of } 1978 \text {. }\end{array}$ & $\begin{array}{l}\text { Census data from these years organised by wards } \\
\text { were the basis for population analysis. }\end{array}$ \\
\hline $\begin{array}{l}\text { Intercensal growth rates in all wards } \\
1978-1988 \\
1988-2002 \\
2002-2012 .\end{array}$ & $\begin{array}{l}\text { Computations of growth rates by wards and spatially } \\
\text { presenting the results. Identify change in the population } \\
\text { growth patterns of the wards. }\end{array}$ & $\begin{array}{l}\text { Identify wards whose growth rates exceed the } \\
\text { national averages of } 2.5 \text { and have a population above } \\
12000 \text { which is the higher limit for a village. } \\
\text { Establishing largest settlements (built-up area) in the } \\
\text { fast-growing wards and tracing these as small towns. }\end{array}$ \\
\hline $\begin{array}{l}\text { Building density at the largest built- } \\
\text { up area in the town core (referred } \\
\text { here as small towns) as per } \\
\text { populations size of } 2012 \text {. }\end{array}$ & $\begin{array}{l}\text { The digitisation of building as points from high-resolution } \\
\text { archive imagery for years } 2016 / 2017 \text { and calculating point } \\
\text { density of the village/street at the core of a small town. }\end{array}$ & $\begin{array}{l}\text { Establishing the typical building density of a thriving } \\
\text { small town. }\end{array}$ \\
\hline $\begin{array}{l}\text { Number of highway passing } \\
\text { through the centre as per } 2002 \text { data. }\end{array}$ & $\begin{array}{l}\text { Visual counting of roads (directions from the junctions) } \\
\text { passing through the centre. }\end{array}$ & $\begin{array}{l}\text { Establishing the relationship between population } \\
\text { growth rates and transportation (road) functions. }\end{array}$ \\
\hline $\begin{array}{l}\text { Proximity to railway stations as per } \\
2012 \text { data. }\end{array}$ & Proximity analysis & $\begin{array}{l}\text { Establishing the relationship between population } \\
\text { growth rates and the availability of transportation } \\
\text { (railway) services. }\end{array}$ \\
\hline Distance to a closest regional city. & $\begin{array}{l}\text { Proximity analysis (near-table) to the nearest of the three } \\
\text { regional cities existing in the study region. }\end{array}$ & $\begin{array}{l}\text { Influence of the major urban centres on the } \\
\text { population growth of small towns. }\end{array}$ \\
\hline $\begin{array}{l}\text { Distance to the nearest peer (small } \\
\text { town). }\end{array}$ & $\begin{array}{l}\text { Proximity analysis to the nearest small town assuming } \\
\text { there is no significant travel barrier between them. }\end{array}$ & $\begin{array}{l}\text { Catchment declination for each studied small town. } \\
\text { Establishing the relationship between the } \\
\text { concentration level of small towns and their growth- }\end{array}$ \\
\hline
\end{tabular}




\begin{tabular}{|c|c|c|}
\hline Factor & Methods of analysis & The rationale for the analysis \\
\hline $\begin{array}{l}\text { Expansion of farming areas between } \\
1995 \text { and } 2011 .\end{array}$ & $\begin{array}{l}\text { Interpreted land cover data from } 30 \mathrm{~m} \text { Resolution Landsat } \\
\text { imagery of } 1995 \text { and } 2011 . \text { The areas of interest were } \\
\text { established from catchment analysis. }\end{array}$ & $\begin{array}{l}\text { rates. } \\
\text { The relationship between population growth and } \\
\text { expansion of farming areas in the vicinity of a small } \\
\text { town. }\end{array}$ \\
\hline $\begin{array}{l}\text { Influence of administrative } \\
\text { functions as per } 2002 \text { status of the } \\
\text { centres. }\end{array}$ & $\begin{array}{l}\text { Ranking of the centres as } \\
\text { "0" for not hosting any administrative functions; } \\
\text { "1" for hosting district council offices; } \\
\text { "2" for hosting independent town council functions; } \\
\text { "3" for hosting regional administrative offices. }\end{array}$ & $\begin{array}{l}\text { Establishing the relation between hosting political } \\
\text { governance functions and their growth-rates small } \\
\text { towns. }\end{array}$ \\
\hline Proximity to the regional hospital & $\begin{array}{l}\text { Proximity analysis to the nearest district or regional or } \\
\text { any higher order hospital assuming there is no significant } \\
\text { travel barrier. }\end{array}$ & $\begin{array}{l}\text { Establishing the relationship between the availability } \\
\text { of social services (health) and growth-rates of small } \\
\text { towns. }\end{array}$ \\
\hline Proximity to protected areas & $\begin{array}{l}\text { Proximity analysis to the nearest protected area assuming } \\
\text { no barrier and flat surface. }\end{array}$ & $\begin{array}{l}\text { Establishing the relationship between the availability } \\
\text { of natural resources and the growth rates of small } \\
\text { towns. }\end{array}$ \\
\hline Proximity crop processing factory & $\begin{array}{l}\text { Proximity analysis to the crop processing factories } \\
\text { assuming no barrier and flat surface. }\end{array}$ & $\begin{array}{l}\text { Establishing the influence of off-farm jobs and } \\
\text { industries on the growth rates of small towns. }\end{array}$ \\
\hline Influence of large scale farming & $\begin{array}{l}\text { Proximity analysis estates farms assuming no barrier and } \\
\text { flat surface. }\end{array}$ & $\begin{array}{l}\text { Influence of agriculture economy on the growth rates } \\
\text { of small towns. }\end{array}$ \\
\hline $\begin{array}{l}\text { Number of river streams within } 10 \\
\mathrm{~km} \text { radius }\end{array}$ & $\begin{array}{l}\text { Mapping of streams and GIS counting within } 10 \mathrm{~km} \\
\text { radius. }\end{array}$ & $\begin{array}{l}\text { Influence of accessible water for farming or livestock } \\
\text { on the growth rates of small towns. }\end{array}$ \\
\hline
\end{tabular}

The following is the context of the empirical research for studying small towns is the three neighbouring Tanzanian regions, namely, the Coast, Morogoro and Iringa (Figure 1). Iringa region was divided into two regions of Iringa and Njombe in 2012, but this separation occurred outside the study period hence not considered in the analysis. The selection of the regions was based on the fact that they were adjacent to one another and therefore have significantly experienced similar policy influences e.g. all being part of Tanzanian Southern Agriculture Growth Corridor. The analysis uses population data from the census report of 1978 ,
1988, 2002 and 2012. The unit of analysis for the census report is a ward, which is the second lowest rank in the hierarchy of jurisdictions of governance in the country. The ward unit, and not villages unit, is adopted as the unit of analysis because, usually, the lowest thriving urban centre will involve at least two villages. Ward populations data were based on the spatial extent of 1978, therefore even when there have been subdivisions of wards, GIS overlay of subdivided wards made possible to identify combinations of wards that coincide with the configuration of the original wards in 1978.

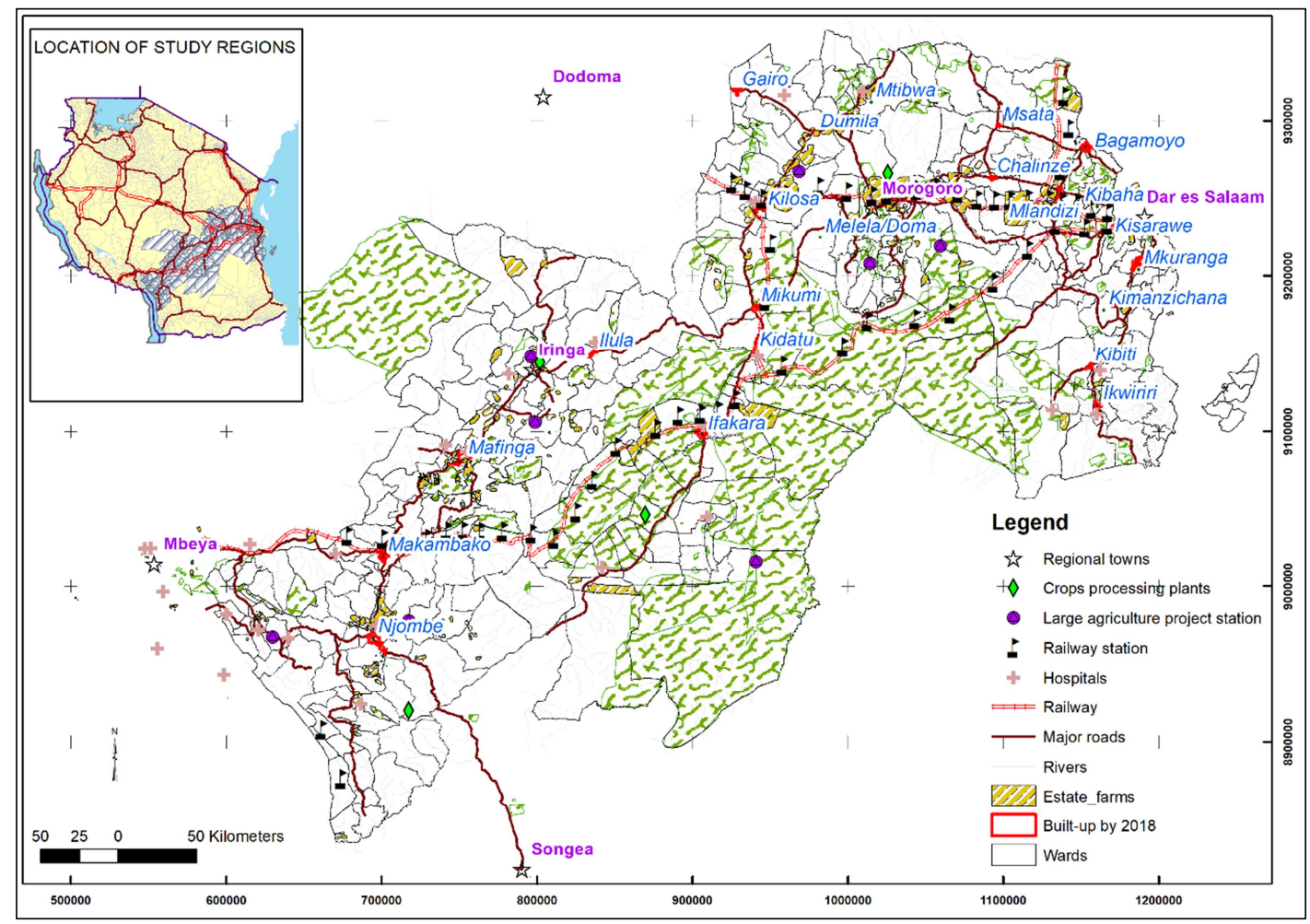

Source: Data from the National Bureau of Statistics and National Land Use Planning Commission

Figure 1. The study area and major facilities. 
The sequence of analysis started with ward level and the wards that showed the trend of growth had their central villages analysed as possible growth poles. The major criteria were those wards that grew beyond the national average population growth rates in. that intercensal period. Twentytwo centres passed to the stage of analysis of growth factors from 258 rural wards initially analysed from the three regions of Morogoro (98 wards) Iringa including Njombe (96 wards) and Coast (64 wards). Considered wards are those which in 2012 census were not part of urban wards for Iringa and Morogoro regional cities.

Data on locations of large estate farms, areas for agricultural projects, crop processing factories, protected areas, railway stations, highways and junctions, number of rivers within $10 \mathrm{~km}$ radius of the town and the locations of the urban centres themselves were captured from census data of 2002. Therefore the facilities were there prior to that year. However, no exact dates for establishment of the facilities and functions were obtained. To be able to calculate building density, data on buildings were generated from by digitising point position of buildings of the most developed (concentrations of buildings) part of the village, forming the centre of a case ward. The raster analysis was done only in areas within the village boundary of core built-up area to establish the point (building) destiny. Through this method densities of the periphery areas of the developed part were omitted to reduce bias, thus making the building data to conform only to the inner parts of the small town.

Data on landcover were established from the land cover series data that Tanzania had undertaken using $30 \mathrm{~m}$ resolutions Landsat data of 1995 and 2012. The data has similar land use classes, and the researcher combined some classes to get more generalised classes of land cover that had changed into farm land.

The limitation of the research is the reliance on secondary data due to the historical and regional nature of the study. Potentially, undertaking empirical research on each of these centres might uncover some of the specific determinants in particular locations. To manage this limitation, the study concentrated on the population analysis whose basic data are available through census and used three intercensal census periods to expand the wideness of the data sample. Approaching the identifications of small towns from regional level analysis and undertaking a study in neighbouring regions which have experienced similar policy context, have increased the normalisation of the data.

\section{Results}

The ward level analysis was done on the cases and the following results are established. There were 57 wards as per 1978 wards configuration that showed to grow above what has been consistently national average growth rate of 2.5 per cent per year (see Tanzania census reports of 1978, 1988, 2002 and 2012) in any of the census and had attained a population size of 12000 people. Some of the 57 wards were in isolation while others were neighbouring each other. The results showed that whenever a ward or collections of neighbouring wards had population growth above 2.5 per annum, the surrounding wards tended to have negative populations growth rates (Figure 2). This finding implies that migration from the surrounding wards played a pivotal role in fuelling the population growth of the fast-growing ward.

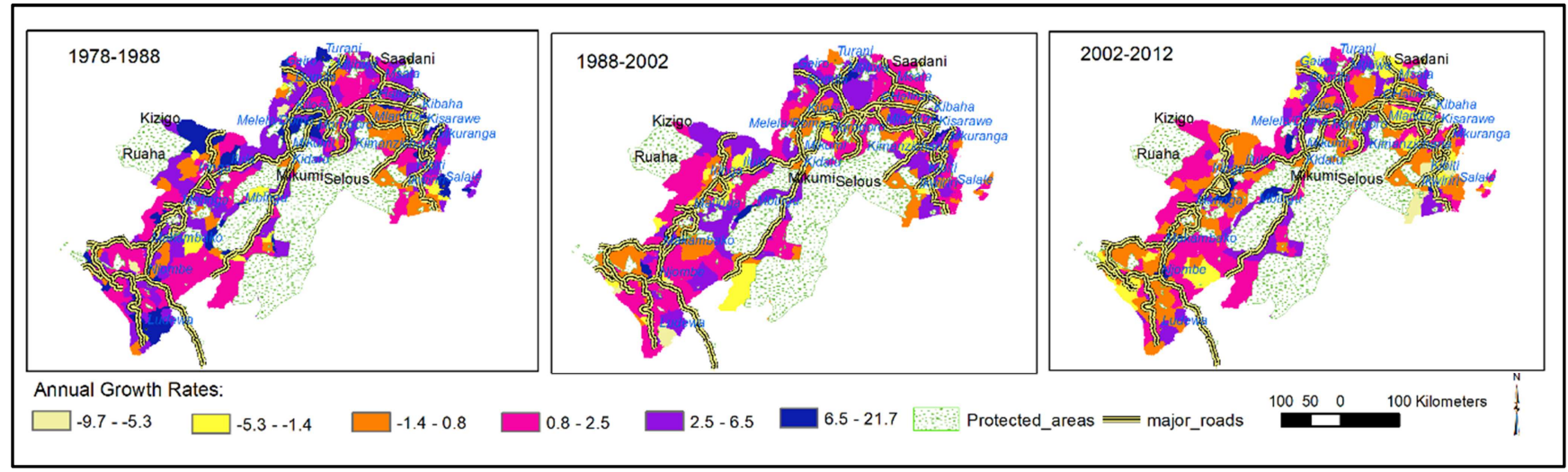

Source: Tanzania Census data of 1978, 1988, 2002 and 2012

Figure 2. Intercensal growth rates.

When the growth rates in all the three intercensal periods were correlated with populations sizes of the growth centres, it was found that there was a strong correlation with the significance level of 0.563 , and $\mathrm{r}^{2}$ linear regressions coefficient of 0.268 (Figure 3). This implies that population growth rates and size influenced one another by at least 27 per cent. Wards whose growth rates correlated strongly with their population sizes had a population size ranging between 12000 and 45000. The population growth rates were observed to be higher when the population of the growth centres was below 30,000 people and maintained at around 2.5 per cent per year when was around 40,000 . 


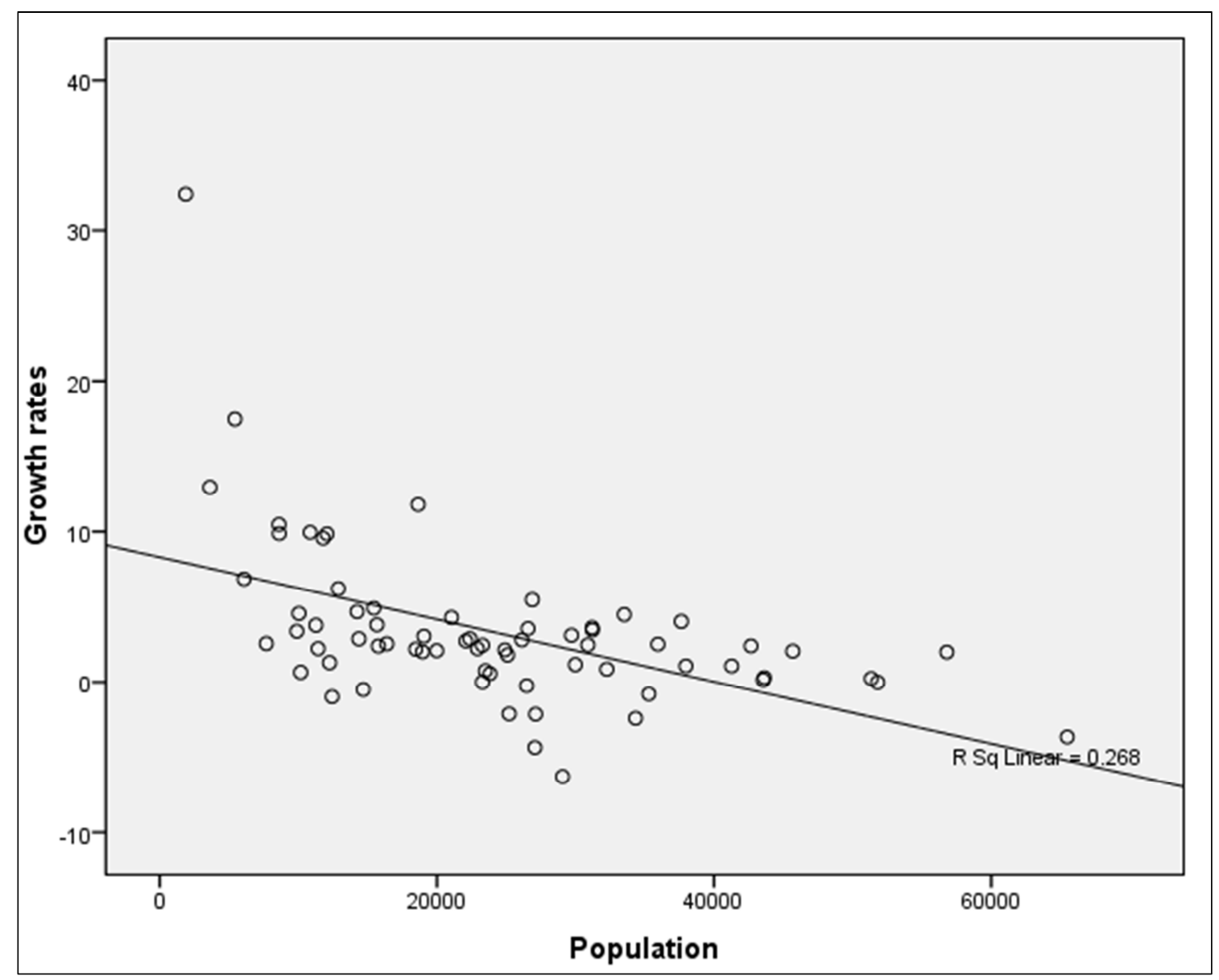

Source: Tanzania Census data of 1978, 1988, 2002 and 2012

Figure 3. Correlation of population size and growth rates.

For the detailed study, 22 wards were selected considering the equality in spatial distribution, having positive growth rates in the intercensal periods of 2002-2012 and having known a settlement centre which could be classified as a small town. For these 22 wards, the central settlements were established using high resolution satellite imagery and village boundaries maps, and, these settlements were studies as small towns.

Table 2. Correlation of growth rates and population size.

\begin{tabular}{lllll}
\hline & & Population & Growth rates \\
\hline & \multirow{3}{*}{ Population } & Correlation Coefficient & Populations & $-.563^{* *}$ \\
Spearman's rho & Sig. (2-tailed) &. & .000 \\
& & $\mathrm{~N}$ & 69 & 69 \\
& \multirow{3}{*}{ Growth rates } & Correlation Coefficient & $-.563^{* *}$ & 1.000 \\
& & Sig. (2-tailed) & .000 &. \\
& $\mathrm{~N}$ & 69 & 69 \\
\hline
\end{tabular}

**. Correlation is significant at the 0.01 level (2-tailed).

Source: Tanzania Census data of 1978, 1988, 2002 and 2012

The mean density of the inner part of the small towns, which forms the central village of the wards, was found to range between 10-30 buildings per hectare. This gives an average gross plot size of between $300 \mathrm{~m}^{2}$ to $1000 \mathrm{~m}^{2}$ per house. Assuming a typical occupancy of four people per dwelling unit [34], the centres of the small towns have a gross density between 4000 to 12000 people per $\mathrm{km}^{2}$.

On the spatial distributions of the centres, they space themselves between 2 to $77 \mathrm{~km}$ with 80 per cent of them spaced between 25 and $60 \mathrm{~km}$ apart. This is the equivalent of one to two hours travel time for those living in the midpoint of the neighbouring small towns. This is the tolerance level of the travel time for people to obtain the rank of services provided by these towns.

Proximity analysis was conducted to assess the influence of different factors on the growth of small towns (see the appended table of indicators). The distributions indicators were presented by Principal Components Analysis (PCA) to establish a general trend of relationships among the factors. The result of the analysis is as presented in figure 4, 5 and 6. 


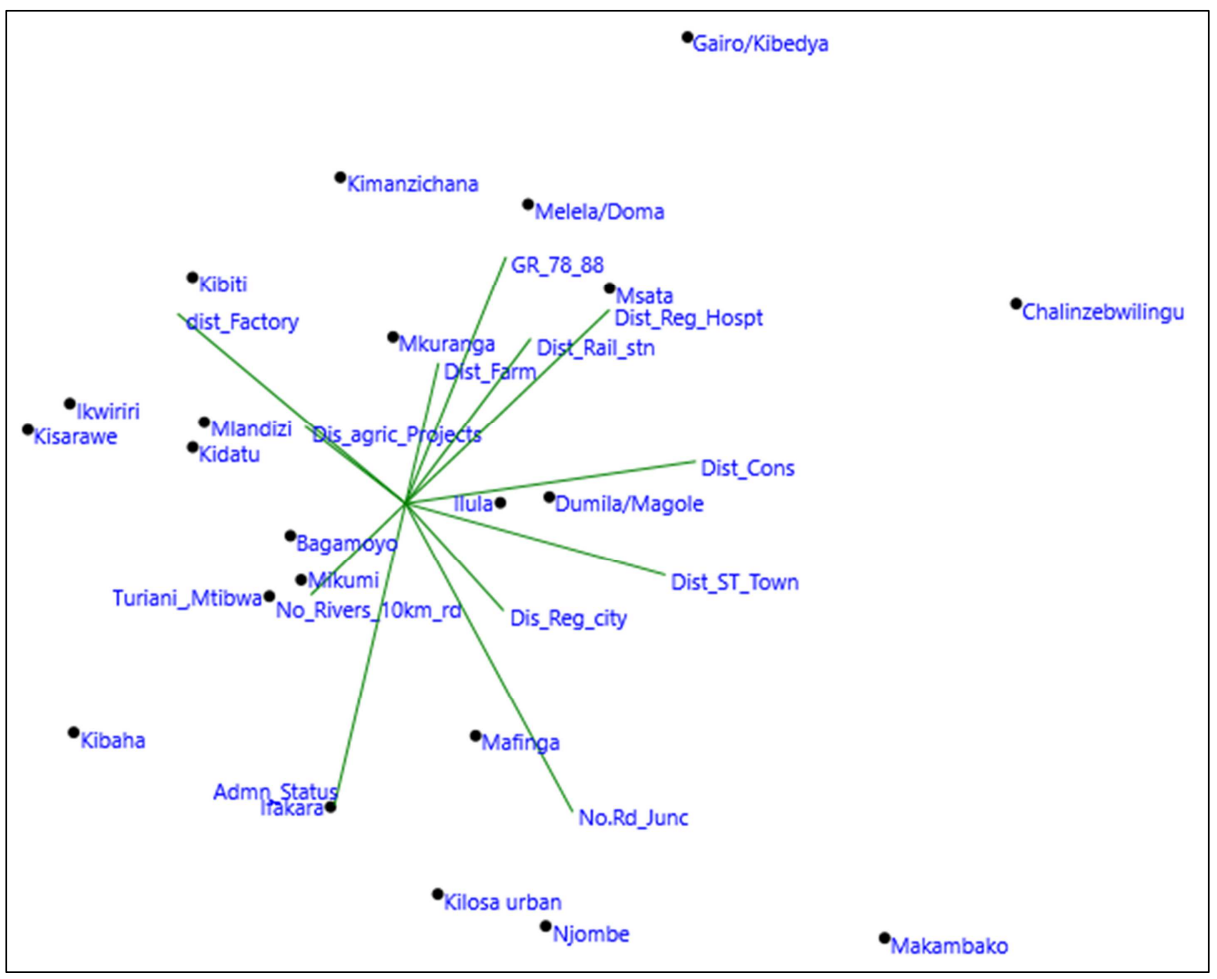

Source: Proximity analysis of data from census and National Lands Use Plan 2012

Figure 4. Relationships between various proximity factors and the 1978-1988 population growth rates.

The growth rate in the intercensal period of 1978-1988 correlated with the proximity of the small towns to large estate farms, crop processing factories, governmentsponsored agricultural projects and centres of social services like hospitals (Figure 4). Proximity to major roads and road junctions was not an important factor for their population growth in this period. It should be noted that prior to 1985 Tanzania development policies were aligned with a socialistic economy and therefore rural production activities were actively supported by the central government through integrated regional development plans [10].

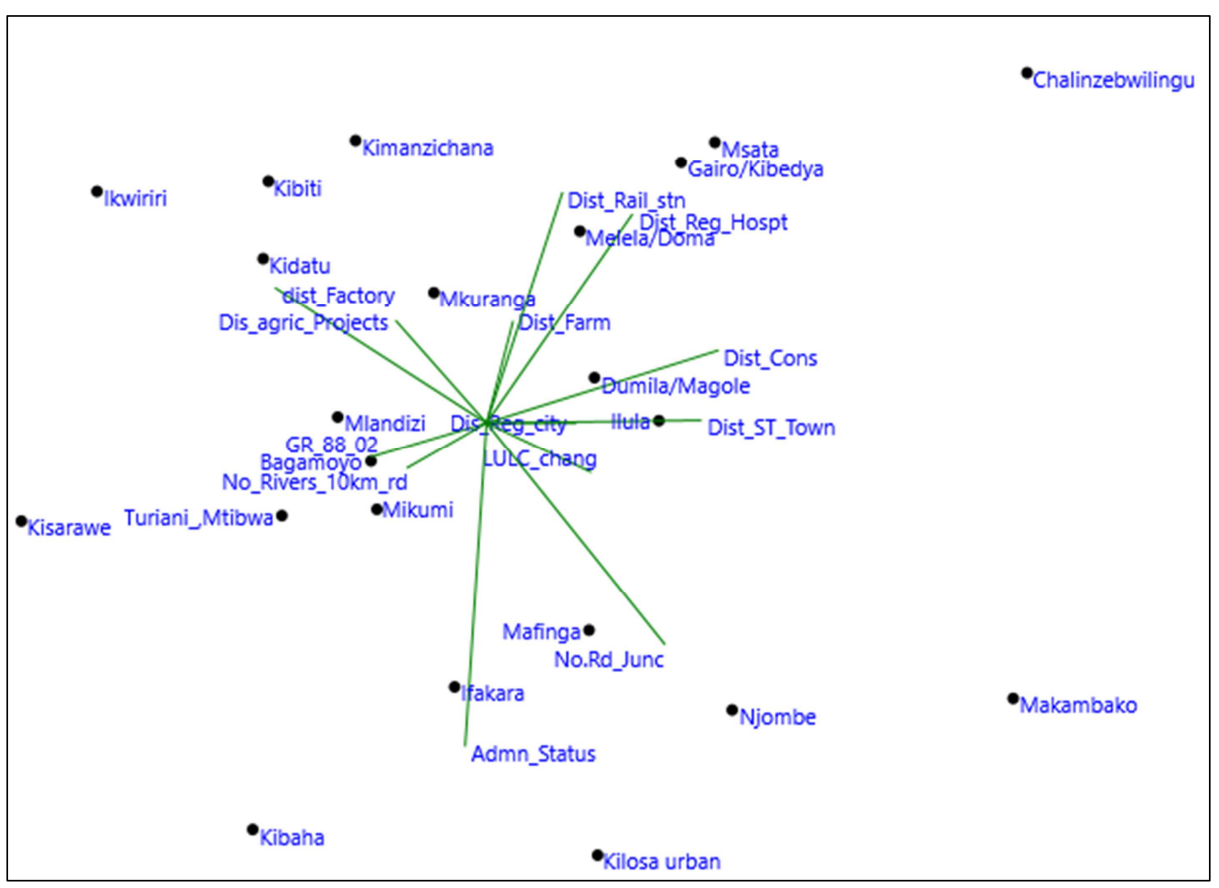

Source: Proximity analysis of data from census and National Lands Use Plan 2012

Figure 5. Relationships between various proximity factors and the 1988-2002 growth rate population growth rates. 
For the intercensal period of 1988-2002, the proximity analysis and PCA showed that growth rate correlated with the proximity to farms, crop processing factories, agricultural projects, and the natural resource endowments like rivers. In this period small towns developed and grew away from conurbations areas where there are regional cities and other small towns. Areas surrounded by conservation activities registered lesser quantities to growth rates.

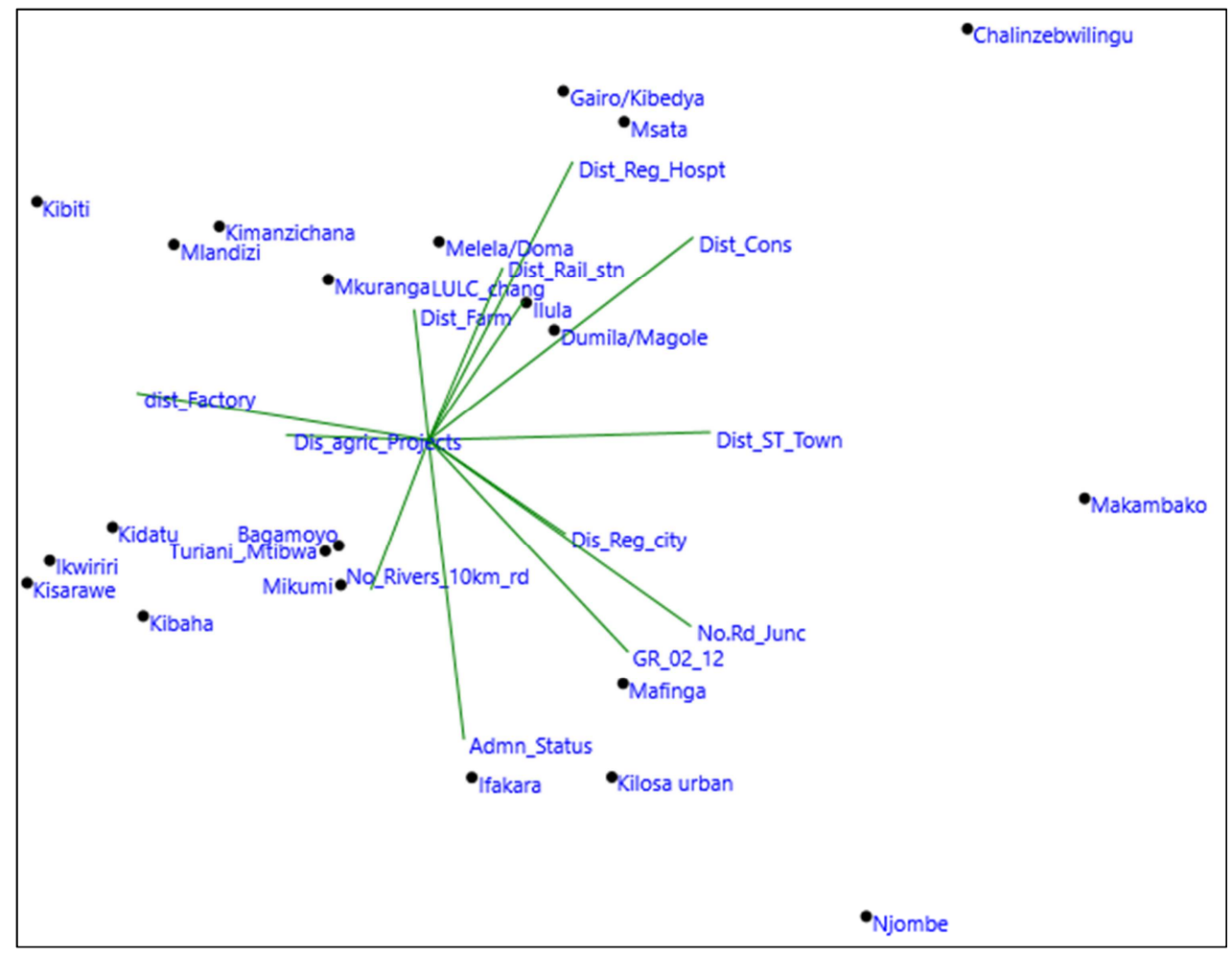

Source: Proximity analysis of data from census and National Lands Use Plan 2012

Figure 6. Relationships between various proximity factors and the 2002-2012 growth rate population growth rates.

The last epoch, 2002-2012, reveals a fully phase of economic liberalism where proximity to trunk roads and its junctions, proximity to other small towns and regional cities and the administrative status of the town were the main factors that correlated positively with the growth rate in that time. Proximity to factories and national agricultural projects had limited impact on the population growth rates.

In general, the factors that seem to work together and correlate consistently with growth rates are proximity to other small towns and regional cities, crop processing agricultural land for expansion and projects as well as natural resource base represented by rivers. However, in recent trends as shown by Figure 6, there is an increasing influence of highway accessibility and conurbation of urban areas. This implies factors related to productions and agglomeration economies propel further population growth of small towns.

From the PCA, there emerged patterns that indicate that deferent factors had a specific influence on the growth of different set of towns. The first set of towns among the 22 studied, are those that do not have administrative status, they are at least one hour drive from regional cities and they registered a huge expansion of agricultural land. Transport network either through railway or trunk road has also a strong influence in their growth. These include Ilula, Gairo,
Msata, Chalinze, Kibiti, Kimanzichana, Mlandizi and Melela. The other set is the fastest growing small towns which are administrative and economic centres. They include Njombe, Kisarawe, Mafinga, Kibaha, Ifakara, Mkuranga, Kilosa and Makambako.

\section{Discussion}

The first study objective was to define contextually the meaning of small towns from the population size and density considerations. The results of the study show that small towns emerge through the polarisation process as they attract populations of the immediate soundings while they themselves feed into population growth of larger urban centres. This conforms to the observations made earlier in a different context [36]. The results also indicate that, like the rest of Sub-saharan Africa [37] Tanzania is still in the process of urban growth, which is far from being stabilised, as only one of the 22 small towns has registered negative average growth rate for the three intercensal periods.

The results of the analysis on the sampled towns show that the population size of the typical small town which is vibrantly growing will be between around 12,000 to 45,000 people, and will tend to grow above the rates of the surrounding settlements. This is in conformity with many 
authors who have argued the populations limit of small towns to be below 50,000 people [30, 31, 46]. The consolidated part of the towns tend to have a gross population density of between 4000-12000 people per square kilometre and building density between 10-30 buildings per hectare. The implied plots sizes are between $300 \mathrm{~m}^{2}$ and $-1000 \mathrm{~m}^{2}$. Considering the fact that many of these towns are not planned, this density indicates the average plot size effectively demanded by small-town residential housing developers.

The second questions the paper attempted to contribute to, is the identification of factors for populations growth in small towns. The findings reveal that economic activities are playing the leading role in the attraction of population. In this research context where over three-quarters of the labour force are engaged in agriculture, this was depicted by the dominating influence of proximity to large scale farms, government-sponsored agricultural projects and crop processing. To qualify further this answer, while agriculture is everywhere in rural Tanzania, it is commercialised agriculture and other activities in the agricultural value chains which generate the type of employment and economic opportunities attractive to people in nearby wards.

Transportation, trading and informal servicing sector supported by the proximity to major roads and important junctions are becoming influential activities for attracting population. Government policies and interventions through the designation of administrative centres which are bundled with accompanied services and employment opportunities is another visible factor for population growth of small towns. The research also presupposes that there is a reversal influence in which the availability of roads and adequate population sizes lure the decision makers into establishing district council offices in such small towns.

While most towns, especially in the economic liberalism era, are growing up along the trunk roads, the influence of the railway as a means of transport is very limited after 2002 . This finding contradicts with some findings in another context [31]. It is also evident that government policies towards rural productions have a significant influence on the growth of small towns.

\section{Conclusion and Policy Recommendations}

The study concludes that despite the wide variations in defining small towns, in Tanzania and similar contexts, the population size that will make a settlement demonstrate typical characteristics of a small town will range between 12000 and just below 50000, that is, 4000-12000 per hectare or 10-30 buildings per hectare. The impetus for the growth of these centres will likely be commercialised agriculture and other activities in the agricultural value chains which generate off-farm employment and economic opportunities attractive to people in nearby areas. Transportation, trading and informal servicing sector supported by the proximity to major roads have important roles in liberalised economies and where development activities are less controlled.

While further research is required to trace the growth history of these towns and relate to these statistical attributes, it suffices at this juncture to put forward some of the policy implications of the study in shaping urbanisation landscape in Tanzania and in areas with similar contexts. It is evident that small towns are essential and are bound to emerge, however for a proper functionality they need to be available at about one-hour drive from their hinterland. They are likely to grow if there is commercial agriculture or some value addition activities. Equally, whenever there is well performing commercial agriculture project with accompanied off-farm employment opportunities and existing important highway junctions, there is the likelihood of the area to emerge as a fast-growing urban centre. Such areas require immediate interventions to ensure their developments are guided. As they consolidate, small towns could be planned with a rather higher and medium density of buildings with plot sizes between $300 \mathrm{~m}^{2}$ and $1000 \mathrm{~m}^{2}$. Designations of the status of district administrative centres can speed the process but may not be the primary factor for their population growth.

\section{Acknowledgements}

I acknowledge the funding received from SIDA for undertaking this research, and support given by my research assistant Mr. Jordan Landulila.

\section{Appendix}

Table 3. Data Generated and Used for the Analysis.

\begin{tabular}{|c|c|c|c|c|c|c|c|c|c|c|}
\hline \multirow{2}{*}{ WARD_NAME } & \multicolumn{4}{|c|}{ Population } & \multirow{2}{*}{ - Area in (km2) } & \multirow{2}{*}{$\begin{array}{l}\text { Built-up Area } \\
(\mathrm{km} 2)\end{array}$} & \multirow{2}{*}{ Dwellings } & \multicolumn{3}{|c|}{ Growth rates } \\
\hline & 1978 & 1988 & 2002 & 2012 & & & & $1978 \_1988$ & $1988 \_2002$ & $2002 \_2012$ \\
\hline Gairo & 1878 & 31198 & 51339 & 52578 & 3.0 & 10.3 & 3413 & 32.5 & 3.6 & 0.2 \\
\hline Kisarawe & 6081 & 11788 & 42662 & 54053 & 6.0 & 3.1 & 2929 & 6.8 & 9.6 & 2.4 \\
\hline Melela & 5423 & 27121 & 19984 & 24559 & 1124 & 0.6 & 217 & 17.5 & -2.1 & 2.1 \\
\hline Chalinze / Bwilingu & 8620 & 22091 & 32259 & 35149 & 3.6 & 5.1 & 2827 & 9.9 & 2.7 & 0.9 \\
\hline Kimanzichana & 12070 & 30888 & 43546 & 44172 & 6.1 & 3.6 & 2000 & 9.9 & 2.5 & 0.1 \\
\hline Mtibwa & 10170 & 10851 & 41269 & 45890 & 471.8 & 3.4 & 2058 & 0.7 & 9.9 & 1.1 \\
\hline Njombe & 23828 & 25213 & 18643 & 56912 & 359.9 & 48.6 & 14998 & 0.6 & -2.1 & 11.8 \\
\hline
\end{tabular}




\begin{tabular}{|c|c|c|c|c|c|c|c|c|c|c|}
\hline \multirow{2}{*}{ WARD_NAME } & \multicolumn{4}{|c|}{ Population } & \multirow{2}{*}{ Area in ( $\mathrm{km} 2)$} & \multirow{2}{*}{$\begin{array}{l}\text { Built-up Area } \\
(\mathrm{km} 2)\end{array}$} & \multirow{2}{*}{ Dwellings } & \multicolumn{3}{|c|}{ Growth rates } \\
\hline & 1978 & 1988 & 2002 & 2012 & & & & 1978_1988 & 1988_2002 & 2002_2012 \\
\hline Kilosa & 12887 & 23500 & 26131 & 34425 & 171.8 & 12.8 & 6724 & 6.2 & 0.8 & 2.8 \\
\hline Mikumi & 7690 & 9895 & 15775 & 19977 & 1319 & 7.1 & 3347 & 2.6 & 3.4 & 2.4 \\
\hline Mkuranga & 10048 & 15672 & 26478 & 25847 & 228.1 & 22.8 & 3750 & 4.6 & 3.8 & -0.2 \\
\hline Ifakara & 22382 & 29718 & 45684 & 55956 & 265.1 & 33.6 & 12360 & 2.9 & 3.1 & 2.05 \\
\hline Dumila / Magole & 16386 & 21054 & 37967 & 42242 & 758.1 & 8.4 & 5187 & 2.5 & 4.3 & 1.1 \\
\hline Bagamoyo & 18471 & 22928 & 31219 & 43793 & 765.1 & 21.9 & 7069 & 2.2 & 2.2 & 3.4 \\
\hline Makambako & 34339 & 26888 & 56797 & 69166 & 253.0 & 28.0 & 14897 & -2.4 & 5.5 & 2.0 \\
\hline Ikwiriri & 12436 & 11268 & 18967 & 23136 & 245.4 & 9.4 & 5752 & -0.9 & 3.8 & 2.0 \\
\hline Kibaha & 26574 & 37638 & 65485 & 45083 & 33.7 & 99.4 & 9063 & 3.5 & 4.0 & -3.7 \\
\hline Ilula & 35948 & 43625 & 51802 & 52179 & 762.3 & 5.2 & 3832 & 2.5 & 0.3 & -0.02 \\
\hline Mlandizi & 11431 & 14242 & 27066 & 17318 & 116.5 & 17.4 & 5811 & 2.2 & 4.7 & -4.4 \\
\hline Kidatu & 25091 & 29991 & 35293 & 32589 & 237.0 & 7.3 & 6069 & 1.8 & 1.2 & -0.8 \\
\hline Kibiti & 14373 & 19067 & 29067 & 15156 & 695.8 & 7.5 & 2521 & 2.9 & 3.0 & -6.3 \\
\hline
\end{tabular}

\begin{tabular}{|c|c|c|c|c|c|c|}
\hline WARD_NAME & $\begin{array}{l}\text { Dwelling density } \\
(\mathrm{p} / \mathrm{km} 2)\end{array}$ & $\begin{array}{l}\text { Planner Distance to } \\
\text { Region city in } \mathrm{km}\end{array}$ & $\begin{array}{l}\text { Distance in } \mathrm{km} \text { to the } \\
\text { next Small town }\end{array}$ & $\begin{array}{l}\text { Land use change } \\
\text { to farms }\end{array}$ & $\begin{array}{l}\text { No.Rivers_10km_r } \\
\text { adius }\end{array}$ & $\begin{array}{l}\text { Administrative } \\
\text { status }\end{array}$ \\
\hline Gairo & 0.07 & 116 & 57 & 64 & 4 & 0 \\
\hline Kisarawe & 0.04 & 26 & 22 & 21 & 5 & 1 \\
\hline Melela & 0 & 39 & 39 & 21 & 5 & 0 \\
\hline Chalinze / Bwilingu & 0.06 & 79 & 77 & 37 & 9 & 0 \\
\hline Kimanzichana & 0.02 & 65 & 34 & 21 & 6 & 0 \\
\hline Mtibwa & 0.04 & 68 & 33 & 29 & 16 & 1 \\
\hline Njombe & 0.31 & 149 & 63 & 29 & 8 & 2 \\
\hline Kilosa & 0.14 & 70 & 40 & 34 & 9 & 2 \\
\hline Mikumi & 0.07 & 99 & 28 & 12 & 4 & 1 \\
\hline Mkuranga & 0.18 & 34 & 61 & 27 & 5 & 1 \\
\hline Ifakara & 0.26 & 118 & 49 & 30 & 28 & 1 \\
\hline Dumila / Magole & 0.12 & 61 & 41 & 24 & 5 & 0 \\
\hline Bagamoyo & 0.15 & 54 & 40 & 18 & 6 & 1 \\
\hline Makambako & 0.31 & 147 & 63 & 50 & 5 & 1 \\
\hline Ikwiriri & 0.12 & 125 & 25 & 9 & 28 & 0 \\
\hline Kibaha & 0.19 & 31 & 21 & 61 & 9 & 3 \\
\hline Ilula & 0.08 & 41 & 42 & 50 & 1 & 0 \\
\hline Mlandizi & 0.12 & 57 & 26 & 71 & 9 & 0 \\
\hline Kidatu & 0.13 & 120 & 51 & 6 & 5 & 0 \\
\hline Kibiti & 0.05 & 103 & 25 & 39 & 4 & 0 \\
\hline
\end{tabular}

\begin{tabular}{|c|c|c|c|c|c|c|c|}
\hline WARD_NAME & $\begin{array}{l}\text { Distance to } \\
\text { estate Farm }\end{array}$ & $\begin{array}{l}\text { Distance to } \\
\text { protected Area }\end{array}$ & $\begin{array}{l}\text { Distance to Crop } \\
\text { Factory }\end{array}$ & $\begin{array}{l}\text { Distance to } \\
\text { agriculture projects. }\end{array}$ & $\begin{array}{l}\text { No. of Road } \\
\text { junctions }\end{array}$ & $\begin{array}{l}\text { Distance to } \\
\text { Railway station }\end{array}$ & $\begin{array}{l}\text { Distance to } \\
\text { Regional_Hospital }\end{array}$ \\
\hline Gairo & 24 & 22 & 110 & 140 & 1 & 59 & 30 \\
\hline Kisarawe & 7 & 0 & 148 & 109 & 1 & 8 & 1 \\
\hline Melela & 14 & 17 & 59 & 36 & 1 & 32 & 40 \\
\hline Chalinze / wilingu & 10 & 31 & 67 & 55 & 3 & 144 & 69 \\
\hline Kimanzichana & 10 & 12 & 164 & 113 & 1 & 54 & 39 \\
\hline Mtibwa & 2 & 6 & 47 & 64 & 1 & 60 & 9 \\
\hline Njombe & 0 & 10 & 51 & 52 & 3 & 63 & 1 \\
\hline Kilosa & 1 & 17 & 83 & 34 & 4 & 1 & 7 \\
\hline Mikumi & 24 & 1 & 120 & 78 & 3 & 7 & 31 \\
\hline Mkuranga & 13 & 18 & 172 & 128 & 1 & 35 & 30 \\
\hline Ifakara & 27 & 1 & 63 & 1 & 3 & 13 & 1 \\
\hline Dumila / Magole & 1 & 21 & 53 & 26 & 2 & 34 & 31 \\
\hline Bagamoyo & 1 & 6 & 131 & 113 & 2 & 20 & 34 \\
\hline Makambako & 1 & 35 & 1 & 44 & 4 & 11 & 30 \\
\hline Ikwiriri & 1 & 3 & 201 & 143 & 1 & 103 & 5 \\
\hline Kibaha & 12 & 8 & 136 & 104 & 2 & 1 & 1 \\
\hline Ilula & 30 & 9 & 35 & 40 & 3 & 62 & 1 \\
\hline Mlandizi & 1 & 7 & 110 & 89 & 1 & 1 & 26 \\
\hline Kidatu & 15 & 1 & 126 & 931 & 2 & 20 & 1 \\
\hline Kibiti & 10 & 9 & 179 & 225 & 1 & 82 & 1 \\
\hline
\end{tabular}




\section{References}

[1] UN-HABITAT, (2009a). The Global Report on Human Settlements: The State of African Cities 2008: A Framework for Addressing Urban Challenges In Africa. UN-Habitat, Nairobi.

[2] UN-HABITAT, (2009b). National Urban Profile, Tanzania, UN-Habitat, Nairobi.

[3] UN-HABITAT, (2009c). Planning Sustainable Cites Human Settlement Reports on experiences of Sustainable Cities Programme. UN-HABITAT, Nairobi.

[4] United Nations Population Division, (2011). World Urbanization Prospects: The 2011 Revision, United Nations Department of Economic and Social Affairs, New York.

[5] Turcotte, M. (2005). Social engagement and civic participation: Are rural and small town populations really at an advantage? (pp. 21-006). Statistics Canada, Agriculture Division.

[6] Kunzmann, K. R. (2010). Medium-sized towns, strategic planning and creative governance. In Making Strategies in Spatial Planning (pp. 27-45). Springer

[7] Shaw, D. (2002). Review Essay Small Towns and NineteenthCentury Urbanization. Journal of Urban History, 28 (2), 220230.

[8] Caplan, K. \& Harvey, E. (2010): Small Town Water and Sanitation Delivery: Taking a Wider View. WaterAid Report. WaterAid.

[9] Baker, J., \& Pedersen, P. (1992). The rural-urban interface in Africa: expansion and adaptation. Nordiska Afrikainstitutet; Centre for Development Research, Copenhagen

[10] Kauzeni, A. S., Kikula, I. S., Mohamed, S. A., Lyimo, J. G., \& Dalal-Clayton, D. B. (1993). Land use planning and resource assessment in Tanzania: a case study. IIED environmental planning issues, (3), 132.

[11] Owusu, G. (2005). Small Towns in Ghana: Justifications for their Promotion under Ghana's Decentralisation Programme; African Studies Quarterly, 8 (2).

[12] Kombe, W. J. (2005). Land use dynamics in peri-urban areas and their implications on the urban growth and form: the case of Dar es Salaam, Tanzania. Habitat International, 29 (1), 113-135.

[13] Halla, F. (2005). Critical elements in sustaining participatory planning: Bagamoyo strategic urban development planning framework in Tanzania. Habitat International, 29 (1), 137-161.

[14] UNFPA (United Nations Fund for Population Activities). (2008). Linking population, poverty and development. UNFPA Population Issues. Available via https://www.unfpa.org/pds/urbanization.htm. Accessed 13 Mar 2014.

[15] Wisner, B., Pelling, M., Mascarenhas, A., Holloway, A., Ndong, B., Faye, P., \& Simon, D. (2015). Small Cities and Towns in Africa: Insights into Adaptation Challenges and Potentials. In Urban Vulnerability and Climate Change in Africa (pp. 153-196. Springer International Publishing.

[16] Hanna, K. S., Dale, A., \& Ling, C. (2009). Social capital and quality of place: Reflections on growth and change in a small town. Local Environment, 14 (1), 31-44.

[17] Meijers, E. J., Burger, M. J., \& Hoogerbrugge, M. M. (2016). Borrowing size in networks of cities: City size, network connectivity and metropolitan functions in Europe. Papers in Regional Science, 95 (1), 181-198.

[18] Waitt, G., \& Gibson, C. (2009). Creative Small Cities: Rethinking the Creative Economy in Place. Urban Studies, 46 (5-6), 1223-1246.

[19] Sharma, K. (2012). Rejuvenating India's Small Towns. Economic \& Political Weekly, 47 (30), 63-68.

[20] Tanzania National Audit Office (2014). Performance Audit Report on the Management of Urban Planning in Tanzania. Dar es Salaam Government Press.

[21] Kyessi, A. (2013). Planning of Border Towns: The Case of Strategic Urban Development Plan for Tunduma Township, Mbeya Region, Tanzania, Paper Presented at a Research Workshop on Transborder Urban Networks and Urban/Regional Dynamics in Africa, held at the Nordic Africa Institute, Uppsala, Sweden, December 2-3, 2013.

[22] Chigara, B; Magwaro-Ndiweni, L; Mudzengerere, F. H \& Ncube, A. B. (2013). An Analysis of the Effects of Piecemeal Planning on Development of Small Urban Centres in Zimbabwe: Case Study of Plumtree, International Journal of Management and Social Sciences Research, 2 (4), 139-148.

[23] Halsall, J. (2012). Community Governance - Where did it all go wrong? Journal of Administration and Governance JOAAG, 7 (2), 1-8.

[24] Huang, C., Namangaya, A., Weber, M., \& Cantada, I. (2017) Urban Planning Study for Tanzania - Impact and Effectiveness of Urban Planning on City Spatial Development. World Bank Group.

[25] Bell, D., \& Jayne, M. (2009). Small Cities? Towards a Research Agenda. International Journal of Urban and Regional Research, 33 (3), 683-699.

[26] Pacione, M. (2009). Urban geography-a global perspective, Routledge. New York.

[27] Maier, K. (2005). Czech housing estates: Recent changes and new challenges. Geographia Polonica, 78 (1), 39.

[28] Steinführer, A., Vaishar, A., \& Zapletalová, J. (2016). The small town in rural areas as an underresearched type of settlement. Editors' introduction to the special issue. European Countryside, 8 (4), 322-332.

[29] Zuzanska-Zysko, E. (2005). Economic transformation of small Silesian towns in the years 1990-1999. Geographia Polonica, 78 (1), 137.

[30] Raman, B. (2017). Practices of territory in small and medium cities of South India. In Subaltern urbanisation in India (pp. 235-260). Springer, New Delhi.

[31] Pryadko, I. (2018). Development of small Russian towns in the 19th-21st centuries: socioeconomic factors. In MATEC Web of Conferences (Vol. 193, p. 01019). EDP Sciences.

[32] Muzzini, E., \& Lindeboom, W. (2008). The urban transition in Tanzania. Building the Empirical Base for Policy Dialogue, 1166. 
[33] United Republic of Tanzania (URT).(2000). Human Settlement Development policy. Government Publisher, Dar es Salaam.

[34] Rebernik, D. (2005). Urbanization trends and processes of population change in the Ljubljana urban region in the 1990s. Geographia Polonica, 78 (1), 67.

[35] Gordon, P., \& Richardson, H. W. (1997). Are compact cities a desirable planning goal?. Journal of the American planning association, 63 (1), 95-106.

[36] Geyer, H. S., \& Kontuly, T. (1993). A theoretical foundation for the concept of differential urbanization. International Regional Science Review, 15 (2), 157-177.

[37] Gwebu, T. D. (2006). Towards A Theoretical Exploration of the Differential Urbanisation Model In Sub-Saharan Africa: The Botswana Case. Tijdschrift Voor Economische En Sociale Geografie, 97 (4), 418-433.

[38] Namangaya, A. (2014). Urban Spatial Planning and Local Economic Development: Comparative Assessment of Practice in Tanzanian Cities: International Journal of Business, Humanities and Technology, 4 (6).

[39] Krumholz, N. (2008). Equitable Approaches to Local Economic Development: in Scott, B. and Faistein, S. (2008). Readings in Planning Theory: Blackwell, Oxford. Glaser, B. G. (1999). The future of grounded theory. Qualitative health research, 9 (6), 836-845.
[40] National Audit Office of Tanzania -NOAT-(2019). Special Audit Report until March 2019: Government Publisher.

[41] Mrema, A. (2015). Contribution of tourist hotels in the socioeconomic development of local communities in Monduli District, Northern Tanzania. Journal of Hospitality Management and Tourism, 6 (6), 71-79.

[42] Meijers, E. J., \& Burger, M. J. (2017). Stretching the concept of 'borrowed size'. Urban Studies, 54 (1), 269-291.

[43] Fujita, M. \& Thisse, J. (2002) Economics of Agglomeration: Cities, Industrial Location, and Regional Growth. Cambridge University Press.

[44] Deng, X., Huang, J., Rozelle, S., Zhang, J., \& Li, Z. (2015). Impact of urbanization on cultivated land changes in China. Land use policy, 45, 1-7.

[45] Masron, T., Yaakob, U., Ayob, N. M., \& Mokhtar, A. S. (2017). Population and spatial distribution of urbanisation in Peninsular Malaysia 1957-2000. Geografia-Malaysian Journal of Society and Space, 8 (2).

[46] Nel, E., Taylor, B., Hill, T., \& Atkinson, D. (2011). Demographic and economic changes in small towns in South Africa's Karoo: Looking from the inside out. In Urban Forum (Vol. 22, No. 4, p. 395). Springer. 